\title{
Los orígenes de Alianza Popular: entre el reformismo institucional y la extrema derecha neofranquista nacional-populista (1976-1979). Un estado de la cuestión
}

\author{
Miguel A. DEl Río Morillas \\ Centre d'Estudis sobre les Ėpoques Franquista i Democràtica \\ Universitat Autònoma de Barcelona (Espanya) \\ orcid.org/0000-0002-6600-9628
}

Presentació: 27 abr. 2015 | Acceptació: 7 juny 2015 | Publicació: 15 des. 2015

Citació recomanada: DEL Río MoriLLAS, Miguel. Los orígenes de Alianza Popular: entre el reformismo institucional y la extrema derecha neofranquista nacional-populista (1976-1979). Un estado de la cuestión. Franquisme \& Transició. Revista d'Història i de Cultura 3 (2015): 301-333. doi: 10.7238/fit.voi3.2699.

Resumen: El presente artículo pretende realizar una revisión crítica de los estudios existentes sobre el partido político Alianza Popular (AP) en el marco de la actual historiografía especializada en el análisis de los movimientos de derecha y extrema derecha europea y española. Todo ello partiendo de una nueva definición política de la inicial AP (1976-1979) como expresión de un nuevo movimiento de extrema derecha europea (la nacional-populista postfascista) como la que representaba, entre otros, el Movimiento Social Italiano (MSI) de Giorgio Almirante. Asimismo, el texto enfatiza los orígenes de la plataforma aliancista en el neofranquismo y el reformismo institucional franquista como punto clave para entender los orígenes del principal partido vertebrador de la actual derecha conservadora española.

Palabras clave: Alianza Popular, neofranquismo, extrema derecha nacional-populista, transición española, derecha española

The origins of Popular Alliance: between institutional reformism and the national populist neo-Francoist far-right (1976-1979). State of the art

Abstract: This article aims to make a critical review of existing studies on the political party Popular Alliance within the framework of the current historiog- 
raphy specialized in the analysis of right-wing and extreme right movements in Europe and Spain. All this based on a new political definition of the initial Popular Alliance (1976-1979) as an expression of a new European rightwing movement (post-fascist and National-populist) like the one represented, among others, by the Italian Social Movement of Giorgio Almirante. The text also emphasizes the origins of the Alliance platform in the neo-Francoism as well as the institutional Francoism reformism as key points to understand the origins of the main backbone party of the current Spanish conservative right-wing.

Keywords: Popular Alliance, neo-Francoism, Far-right populism, Spanish transition, Spanish right-wing

\section{Introducción}

La extrema derecha y la derecha española constituyen aún, a día de hoy, temas poco analizados por la historiografía española actual - exceptuando casos sobresalientes-, en comparación, por ejemplo, con la extensa bibliografía generada por el estudio de los movimientos y partidos de izquierda e extrema izquierda durante el periodo de la denominada transición española. Esta derecha y extrema derecha, entendida como un movimiento sociopolítico más, siempre ha despertado un cierto recelo ético y político por parte de la comunidad científica y de las instituciones públicas, siendo una temática infravalorada dentro de los estudios históricos. Más allá de su interés social, habría que destacar el papel sociopolítico desarrollado en una etapa clave del siglo xx: el tardofranquismo y la transición española. Queremos destacar que el tratamiento de este tema ha estado siempre integrado de una manera muy residual en el desarrollo de la historia del franquismo o de la transición, sin prestarle, creemos, la suficiente atención. En el caso que nos atañe, queremos destacar los estudios existentes sobre lo que consideramos el principal partido de la extrema derecha española neofranquista durante los primeros pasos de la denominada transición española y principal partido vertebrador de la actual derecha española: Alianza Popular (AP). 


\section{Algunas matizaciones sobre AP ${ }^{1}$}

AP tiene sus orígenes en uno de los movimientos reformistas franquistas liderados por Manuel Fraga Iribarne que acabaría viendo la luz como expresión de una plataforma neofranquista de carácter resistencial en octubre de $1976 .{ }^{2}$ En este sentido, es importante destacar la anomalía de la derecha española y del sistema político español en su conjunto, considerando que se trata del único país occidental europeo en el que el partido vertebrador de la derecha procede de la extrema derecha. Entendemos por ésta una AP cuyo signo de identidad fundamental, cuya percepción por la opinión de 1976 y los electores de 1977, fue la lealtad a la obra del régimen de Franco y la reticencia a abrir un periodo constituyente que llegara a deslegitimar la dictadura y a establecer, como valores propios de la España constitucional, los de la democracia vigente en la Europa posterior a la Segunda Guerra Mundial y no los de la simple apertura realizada y controlada por un régimen autoritario postfascista.

Metodológicamente hablando, partimos de una hipótesis como eje primordial: la existencia real de una extrema derecha neofranquista (AP),

1 Sobre el tema, cf. Miguel A. del Río, De la extrema derecha neofranquista a la derecha conservadora. Los orígenes de Alianza Popular, 1973-1979 (tesis doctoral, Universitat Autònoma de Barcelona, 2013).

2 Alianza Popular nace en octubre de 1976 como confluencia de asociaciones políticas nacidas en su mayoría al calor del Estatuto de Asociaciones del Movimiento Nacional de diciembre de 1974. Las siete agrupaciones representaban a la mayoría de culturas políticas ubicadas en el franquismo: 1) Unión del Pueblo Español (UDPE), liderada por Cruz Martínez Esteruelas, recogía los sectores azules, especialmente los funcionarios, de las estructuras del Movimiento Nacional; 2) Unión Nacional Española (UNE), liderada por Gonzalo Fernández de la Mora, de tendencia tradicionalista; 3) Acción Democrática Española (ADE), liderada por Federico Silva Muñoz y que recogía a los sectores católicos colaboracionistas del franquismo; 4) Reforma Democrática (RD), liderada por Manuel Fraga, conglomerado de fuerzas procedentes del reformismo azul joseantoniano y de sectores liberalizantes del franquismo; 5) Acción Regional (AR), liderada por Laureano López Rodó, de tendencia tecnocrática regionalista; 6) Democracia Social (DS), liderada por Licinio de la Fuente, de tendencia neofalangista evolutiva; 7) Unión Social Popular (USP), liderada por Enrique Thomas de Carranza, la cual no se decantaba por ninguna de las cultura políticas del franquismo, al intentar presentarse como una plataforma aglutinante de las fuerzas del 18 de Julio. Legalmente sería inscrita como federación de asociaciones/partido bajo el nombre oficial de Federación de Alianza Popular (FAP), aunque generalmente se la conocía simplemente como Alianza Popular. Integraban la inicial FAP: RD, UDPE, AR, USP, DS (todas ellas unificadas en el Partido Unido de Alianza Popular - PUAP — tras el primer congreso nacional de la federación aliancista en marzo de 1977), más la UNE y ADE. En el presente texto utilizaremos sólo Alianza Popular (AP) para referirnos a FAP/PUAP. 
originaria de los reformistas franquistas, que acaba transformándose en una fuerza de derecha conservadora y que, en el proceso de crisis de un régimen político, opta por la defensa de la legitimidad del franquismo, sin ser capaz de hacerse, en un primer momento, con el apoyo de sectores sociales que han tenido una actitud favorable a Franco. Una AP que llevó hasta las últimas consecuencias estas políticas que claramente podríamos asimilar con las políticas de las fuerzas de la nueva extrema derecha europea del momento, como las del Movimiento Social Italiano (MSI), el Partido Nacional Demócrata de Alemania (NPD) o el Frente Nacional (FN) francés, las cuales se integraban en la denominada extrema derecha nacional-populista postfascista de corte postindustrial. ${ }^{3}$ Estas fuerzas mezclaban el respeto o su comprensión por las experiencias fascistas - sin que por ello se desease su vuelta - con unas políticas que hacían referencia a los problemas del momento y a soluciones no basadas en proyectos pasados. Esta estrategia de ni renegar ni restaurar, se acompañaba de un discurso anticomunista y de crítica, en clave nacional-populista, hacia los sistemas democráticos, mientras se hacía especial hincapié a conceptos aparejados con las sociedades postindustriales como eran la seguridad, la identidad, el orden o la protección. Lógicamente, las actitudes de esta extrema derecha europea varían de forma sustancial de un país a otro, incluyendo en esa variación los diferentes momentos en que el nacional-populismo adquiere alguna presencia electoral y capacidad de condicionamiento. No es lo mismo un MSI surgido de la resistencia inmediata a la Primera República, como movimiento de aglutinación de

3 Entre la abundante bibliografía sobre los casos del MSI, FN francés y NPD, véase, entre otros, Joseph Algacy, L'extrême droite en France (1965 a 1984) (París: L’Harmattan, 1989); Ferran GALlego, Por qué Le Pen (Barcelona: Ediciones de Intervención Cultural, 2002); íd., Neofascistas. Democracia y extrema derecha en Francia e Italia (Barcelona: Plaza \& Janés, 2004); íd., De Auschwitz a Berlín. Alemania y la extrema derecha, 1945-2004 (Barcelona: Plaza \& Janés, 2005); íd., «El MSI y el lugar del fascismo en la cultura política italiana», Studia Storica. Historia Contemporánea 30 (2012): 173-204; Piero Ignazi, Il polo escluso. Profilo del Movimento Sociale Italiano (Bolonia: Il Mulino, 1989); Michael MinkenberG, «The New Right in Germany. The transformation of conservatism and extreme right», European Journal of Political Research 22 (1992): 55-81; Patrick MOREAU, Les héritiers di III Reich. L'extrême droite allemande de 1945 à nos jours (París: Seuil, 1994); Marco TARCHI, Dal MSI ad AN: organizzazione e strategie (Bolonia: Il Mulino, 1997); Bettina WeSTLE \& Oskar NIEDERMAYER, «Contemporary right-wing extremism in West Germany. The Republicans and their electorate», European Journal of Political Research 22 (1992): 83-100, doi: 10.1111/j.1475-6765.1992.tboo306.x. 
los ex combatientes de Saló, o un NPD que consigue unificar diversos movimientos de extrema derecha que fueron apareciendo en el panorama electoral de la República Federal Alemana (RFA) desde comienzos de la década de los cincuenta, y que lograron alcanzar su mayor grado de unidad e incidencia en la segunda mitad de los años sesenta, más como un partido de carácter nacionalista y conservador que como una fuerza neonazi. O el caso del FN, constituido como federación de movimientos ultras en 1973, como acuerdo entre los sectores nacional-revolucionarios de François Duprat, los solidaristas del matrimonio Stirbois y los neopoujadistas de Le Pen, cuya vida transcurrió de forma prácticamente clandestina hasta que el triunfo de Mitterrand en las presidenciales de 1981 y la paralela crisis del gaullismo abrieron un espacio por el que pudo irrumpir un discurso nacional-populista adaptado a nuevas temáticas como la de la inmigración, la seguridad, la lucha contra la globalización y la defensa de la identidad popular francesa. A estos grupos pueden añadirse las posiciones de liberalismo populista nórdico, de carácter antifiscal, que surgió en los partidos progresistas de los años setenta, y los partidos nacionalistas y populistas cuya temática era fundamentalmente la lucha contra la alternancia de democristianos y socialdemócratas en Austria o Alemania, dando lugar a la expansión de los republicanos de Schönhuber o los liberales de Haider. Sea cual sea la variedad de todas estas circunstancias, y no pudiendo considerar que AP pueda pertenecer a los grupos de carácter antisistémico que aparecen en los ochenta y los noventa, lo que interesa aquí es destacar la existencia de un partido de masas que puede calificarse de extrema derecha en sus momentos fundacionales, por su discurso de legitimación de la dictadura, por las actitudes antidemocráticas de sus votantes y simpatizantes, por su actitud ante las fuerzas de la izquierda, que alejan a la AP fundacional de los grupos conservadores liberales o democristianos europeos. La extrema derecha presuntamente ausente del espacio español se encontraba, sin embargo, perfectamente localizable donde más debía esperarse: no tanto en aquellos sectores que reclamaran un anacrónico retorno a las condiciones indeseables de un enfrentamiento civil - como tampoco se demanda el retorno a Saló o al Estado Francés por parte del MSI o del lepenismo-, sino en quienes solicitaban unas garantías de seguri- 
dad que tuvieran su apoyo en la cultura antidemocrática tan firmemente anclada en la conciencia de millones de españoles por cuarenta años de dictadura.

Buena parte de los estudios dedicados a la extrema derecha en este periodo se dedican sólo al análisis de sus sectores más radicales, como los representados por la coalición electoral neofranquista, la Alianza Nacional 18 del Julio -Fuerza Nueva, Falange Española de las JONS (FE-JONS), entre otros-, para afirmar el poco peso electoral que tuvo en la elecciones de 1977 - menos de un $1 \%$-, sin tener en cuenta que la plataforma aliancista en junio de 1977 era la manifestación de otra extrema derecha neofranquista, que sí logró movilizar el voto de gran parte de la misma. Lógicamente las dos expresiones de extrema derecha neofranquista compartían vasos comunicantes, especialmente en su carácter anticonstitucionalista, aunque les diferenciaban sus interpretaciones sobre la adaptación del franquismo a los tiempos imperantes. Así, mientras la extrema derecha neofranquista, agrupada en AP, era de carácter evolutiva y se postulaba por defender un proceso adaptativo del régimen sobre la base del franquismo desarrollista de los años sesenta y de la legitimidad de ejercicio del mismo - sin querer restaurar el franquismo inicial—, la extrema derecha neofranquista de carácter ortodoxo aglutinada por Fuerza Nueva, FE-JONS o la Confederación Nacional de Ex Combatientes, creía en la capacidad evolutiva del régimen sobre las bases del franquismo augural. La capacidad de movilización de AP en las elecciones de 1977 permitiría, a su vez, definirla, instrumentalmente, como una extrema derecha operativa, mientras que las fuerzas neofranquistas ortodoxas unidas en la Alianza Nacional del 18 de Julio, nos permitiría calificarlas como una extrema derecha residual, en tanto que testimonial, no sólo en su aspecto electoral, sino también en su cultura política en relación con lo que la derecha española, incluso la que se sentía próxima al franquismo, podía tener como expectativas razonables de futuro.

Así con todo, la misma evolución de AP, también marcó su misma evolución ideológica y su categorización dentro de la extrema derecha española. En este sentido podemos afirmar que AP deja de representar la extrema derecha nacional-populista postfascista del tipo MSI, cuando ésta acepta entrar en el proceso constituyente que acabaría en la Constitu- 
ción de 1978. Fraga, finalmente, es uno de los ponentes constitucionales, a pesar de haberse opuesto a un proceso constituyente por considerarlo una ruptura del sistema, y lo hace para no quedarse fuera del consenso constitucional. El político gallego era consciente que como mal menor, como pragmatismo político, debía estar en la ponencia constitucional, ya que si no quedaría excluido de los núcleos de poder, y con ello AP quedaría relegada a una fuerza marginal, no ya en votos pero sí institucionalmente, ya que nadie a pesar de tener diputados querría contar con ella, como le sucedió al MSI. Los misinos eran una fuerza anticonstitucional; por ello, a pesar de ostentar representación parlamentaria, ninguna fuerza quería contar con ella: eran, parafraseando al politólogo Piero Ignazi, el polo excluido, il polo escluso. ${ }^{4}$ Ostentaba poder institucional pero nadie quería contar con ella, por lo tanto se le marginaba no teniendo en cuenta sus diputados. Fraga no quería ser il polo escluso español y era consciente de ello. Para remediarlo debía estar en la ponencia constitucional al igual que sus compañeros promotores de AP, a pesar de que no les gustara, ya que se estaban jugando la supervivencia de AP. Para ello AP debería participar en el debate y proceso constitucional y lo acataría - si bien con los problemas internos y contradicciones que ello conllevaba- con el objetivo de no quedarse aislada. Ni quería ser Fuerza Nueva ni MSI, para ello dejaría de ser la extrema derecha anticonstitucionalista que había sido desde su nacimiento - y que explotaría durante la campaña electoral de 1977 como uno de sus rasgos distintivos-, para convertirse en la derecha extrema constitucionalista y con ello caminar sobre los pasos de la una derecha nacional-conservadora. Había otra cuestión: Fraga era un hombre nacido en el Estado, así como la mayoría de los líderes aliancistas - todos ellos altos funcionaros del Estado-, que siempre habían estado dentro del sistema. Fraga nunca hubiera permitido, ya que no estaba en su concepción de la derecha, estar contra el sistema, como hubiera representado oponerse a entrar en el proceso constitucional o votar masivamente en contra. No estaba en el ADN de la derecha representada por Fraga ser una derecha extrema antisistema como 
podía representar Fuerza Nueva, la cual se había convertido en el máximo representante de la misma pasadas las elecciones de junio de 1977.

Por lo tanto, AP y Fraga dejan la extrema derecha anticonstitucionalista a partir de 1977, cuando se abre el debate constitucional y se acepta formar parte de este, pasando a ser la derecha extrema constitucionalista, por miedo a quedar excluidos del sistema. El cambio de definición de AP, por lo tanto, no lo ubicamos en el III Congreso de AP en 1979 con la expulsión de UNE y ADE (los sectores más extremistas que se niegan a aceptar la Constitución) como se había pensado inicialmente, sino en 1977 en los inicios del debate constitucional. El III Congreso Nacional de 1979 sería la ratificación de ese camino al igual que la aceptación a regañadientes, pero pragmática, de una Constitución que no entraba ni en los planteamientos del reformismo franquista ni en los deseos y objetivos de la inicial plataforma aliancista. El acatamiento del texto constitucional y su deseo de reformarla inminentemente volvieron a mostrar la verdadera naturaleza resistencial de AP, especialmente por parte de sus bases, las cuales estaban casi unánimemente en contra de la aprobación de la Constitución. De esa manera se iniciaba el camino de redefinición no rupturista de la plataforma aliancista con su pasado/identidad, pero sí con su táctica política inicial hacia la consecución de la hegemonía de la derecha española a través de una nueva expresión de fuerza conservadora, a saber: una derecha nacional-conservadora constitucionalista.

\section{Alianza Popular en la historiografía}

Los estudios sobre la derecha española o sobre la extrema derecha neofranquista española que focalizan su núcleo de estudio en Alianza Popular son escasos. En este sentido, las monografías sobre AP se han concentrado en un análisis fuera del debate sobre la naturaleza de la plataforma aliancista y sobre su evolución acorde con la crisis orgánica del franquismo y el devenir del reformismo franquista y de la extrema derecha española. En un primer nivel nos encontramos con el trabajo pionero de la investigadora Lourdes López Nieto, la cual realiza un excelente análisis de AP, desde un punto de vista sociológico y politológico, partiendo de 
los inicios de AP hasta las elecciones de $1982 .{ }^{5} \mathrm{~A}$ pesar de ser un trabajo completo, con una gran cantidad de datos y análisis, deja de lado el contexto global donde se desarrolla AP, analizando la plataforma como un ente aislado de su contexto histórico, el cual creemos clave para determinar y comprender la misma evolución de AP. Por consiguiente creemos que no entra en un contexto determinante para comprender qué era AP durante sus inicios, su definición política y su ubicación dentro de las fuerzas neofranquistas de matriz reformista franquista. En un sentido similar nos encontramos el trabajo de la investigadora Elena M. García-Guereta, ${ }^{6}$ donde a pesar de profundizar en el contexto global histórico donde se desarrolla e interactúa AP, acaba sumergiéndose en un análisis sociológico y politológico sobre la misma evolución de AP desde sus inicios hasta 1996. A pesar de ser un completo análisis, en la línea del propuesto por Lourdes López Nieto donde se analizan su organización formal, su funcionamiento interno o su personal político - con una abundante cantidad de datos empíricos-, García-Guereta hace más hincapié en las propuestas programáticas y en la identidad ideológica de la misma AP, aunque sin la necesaria profundización en temas concluyentes para la evolución de AP como podrían ser el contexto histórico y los agentes políticos que interactúan en el quehacer evolutivo de la misma plataforma aliancista. Lógicamente al ser un análisis que llega hasta 1996 sería comprensible esa falta de profusión, aunque se echa en falta un análisis de su mutación ideológica, una referencia al marco comparativo con sus homólogos europeos, así como una propuesta metodológica para definir políticamente e ideológicamente a AP.

5 Lourdes López Nieto, Alianza Popular: Estructura y evolución electoral de un partido conservador (1976-1982) (Madrid: CIS, 1988). Véase, asimismo, otros trabajos de la autora sobre AP, «El centro-derecha en España, 1976-1982», en Lourdes López Nieto, Richard GilLESPIE \& Michael WALLER, eds., Política faccional y democratización (Madrid: CEC, 1995), 51-66; «La constitución de un partido abierto: Alianza Popular/Partido Popular», en Juan Carlos Monedero \& Juan Luís PaniAGUA SoTo, coords., En torno a la democracia en España. Temas abiertos del sistema político español (Madrid: Tecnos, 1999), 233-254; «20 años de Partido Popular. Del aislamiento al liderazgo», Cuadernos de Pensamiento Político FAES 21 (2009): 175-198. Así como otros estudios colectivos como el de Lourdes López Nieto \& Ramón CotaRelo, «Spanish Conservatism, 1976-1987», en Klaus von Beyme, ed., Right-wing Extremism in Western Europe (Londres: Frank Cass \& Co. Ltd., 1988), 80-95.

6 Elena María García-Guer eta RodríGuez, Factoresexternoseinternosen la transformación delos partidos políticos. El caso de AP/PP (Madrid:Centro de Estudios Avanzados en Ciencias Sociales, 2001). 
Siguiendo con la evolución de monografías sobre AP, tenemos que hacer referencia a una extensa y completa investigación, en dos tomos, a manos del investigador Manuel Penella.7 Sin lugar a dudas, podemos afirmar que la presente obra constituye en la actualidad una de las investigaciones de referencia para todos aquellos que quieran indagar en la historia de AP. La extensa fuente de documentos consultados, con una mención especial a los archivos personales del aliancista Félix Pastor Ridruejo y a una extensa documentación sobre GODSA (Gabinete de Orientación y Documentación, S.A.), ${ }^{8}$ dotan al trabajo de una interpretación en parte sesgada de la realidad aliancista. Con todo, su obra nos detalla exhaustivamente la misma intrahistoria de AP desde los inicios, que el autor lo codifica con el nacimiento de GODSA en 1973, hasta la refundación de los aliancista en 1989 bajo las siglas del actual Partido Popular (PP). A pesar de ser una obra referencial, el autor, creemos, en cierta manera intenta proyectar la idea de Fraga, GODSA y RD (Reforma Democrática) como demócratas desde sus inicios, y que como consecuencia de las circunstancias del momento se unen a organizaciones y personalidades no ubicadas en su liberalismo o socialdemocracia, los cuales, a su vez, modifican y distorsionan sus proyectos iniciales como consecuencia de tener que reconducir a la derecha extrema ultramontana hacia la democracia. Rezuma de la misma investigación la imagen de un Fraga y un núcleo central de RD como los auténticos representantes de una AP que tenía que ser democrática y liberal, pero que como consecuencia de sus continuos pactos a contranatura con la extrema derecha franquista, se encalla en unos objetivos no deseados inicialmente.

Por otra parte, también, tenemos que hacer referencia a otra monografía extensa y elaborada sobre los orígenes y evolución de AP hasta su refundación en 1989. El autor, Rogelio Baón, que también inicia su in-

7 Manuel Penella, Los orígenes y la evolución del Partido Popular. Una historia de AP (19731989). 2 vols. (Salamanca: Caja Duero, 2005).

8 Godsa nace en 1973 como sociedad mercantil por los militares Javier Calderón, José Luís Cortina Prieto y Florentino Platero. Se estructura como una sociedad de estudios y de asesoramiento político dentro del sistema franquista. Fraga acabaría siendo el principal cliente de la citada sociedad, con lo que el proyecto político de Fraga y el de GODSA acabarían unificándose en el tiempo, especialmente en $\mathrm{RD}$. 
vestigación en 1973, fecha de nacimiento de GODSA, realiza un análisis en clave militante aliancista (fue entre otros secretario de Manuel Fraga y diputado aliancista durante varias legislaturas). ${ }^{9} \mathrm{~A}$ pesar de la existencia de una amplia fuente documental y de un notable trabajo analítico, el cual es necesario tener en cuenta para cualquier investigador que se aproxime al estudio de AP, su interpretación como parte integrante de AP nos debería limitar la utilización de la presente investigación en una dinámica parecida a como utilizamos unas memorias. ${ }^{10}$ De igual manera interpretamos la obra de José María Velo de Antelo sobre el nacimiento —que inicia en la Ley Orgánica del Estado (LOE) de 1967 y en el asociacionismo franquista - y evolución de AP hasta nuestros días. ${ }^{11} \mathrm{~A}$ pesar de ser una obra de un antiguo militante de AP (fue miembro de la tradicionalista Unión Nacional Española) está escrita desde una posición crítica situada a la derecha del actual PP y que se entroncaría con los actuales sucesores de Fuerza Nueva, el partido Alternativa Española (AES) liderado por el yerno de Blas Piñar, Rafael López-Diéguez. Destaca de su obra, más que su aporte documental — que es nulo-, su aporte personal de los acontecimientos vividos en los orígenes de AP, especialmente hasta su salida de la misma en 1978, base central de su obra. De modo similar, enfatiza el nacimiento de AP como algo más que un proyecto personal de

9 Rogelio BAón, Historia del Partido Popular I. Del Franquismo a la Refundación (Madrid: Ibersaf, 2001).

10 En este sentido otra fuente para aproximarnos al estudio de AP de forma complementaria, sesgada y con las debidas precauciones que encierra todo libro de memorias, son las obras de los principales líderes y miembros iniciales aliancistas, como Manuel Fraga Iribarne, En busca del tiempo perdido (Barcelona: Planeta, 1987); Laureano López Rodó, Claves de la Transición. Memorias, IV (Barcelona: Plaza \& Janés, 1993); Federico Silva MuÑoz, Memorias políticas (Barcelona: Planeta, 1993); Gonzalo FernÁndez de LA MoRA, Río arriba. Memorias (Barcelona: Planeta, 1995); Licinio de la Fuente, Valió la pena (Madrid: Edaf, 1998); Jorge Verstrynge, Memorias de un maldito (Barcelona: Grijalbo, 1999); Alfonso Osorio, De orilla a orilla (Barcelona: Plaza \& Janés, 200o); Rafael Pérez EsCOLAR, Memorias (Madrid: Foca, 2005); Gabriel ElOR RIAGA, El camino de la concordia. De la cárcel al Parlamento (Barcelona: Debate, 2008); Carlos Robles PIQuer, Memoria de cuatro Españas. República, franquismo y democracia (Barcelona: Planeta, 2011). Complementariamente a las memorias también encontramos obras programáticas y de reflexión emitidas por los propios aliancistas; véase, entre otros, Manuel Fraga Iribarne, Alianza Popular (Bilbao: Albia, 1977), o José C. Ruiz MartíNEZ, Mi lucha por un partido: Alianza Popular (Alicante: Gráficas Díaz, 1981).

11 José María Velo de Antelo, De ayer a hoy. Los orígenes del Partido Popular (Madrid: Galland Books, 2010). 
Fraga. Para Velo de Antelo AP fue la plasmación de una plataforma de asociaciones políticas nacidas en el marco regulador del Movimiento Nacional de 1974-1975, erigidas para defender la legitimidad del franquismo en el proceso de cambio, en la que Fraga sería el último en llegar con su RD. Por lo tanto, el autor fija los orígenes de AP, no en GODSA ni en $\mathrm{RD}$, sino en un proyecto global del neofranquismo reformista institucional. Por otro lado, realiza un análisis de la transición bajo una interpretación claramente englobada en una extrema derecha neofranquista de Fuerza Nueva, donde las críticas a la ruptura existente y a la traición al legado de Franco por parte de la clase reformista del franquismo son los comunes denominadores. Asimismo, en un nivel también de militancia destaca una descomunal obra, por su extensión, coordinada por Bernardo Rabassa y formada por seis volúmenes en la que se expone la protohistoria de AP/PP como la plasmación de la evolución lógica del movimiento «centro derecha» español desde 1812 hasta 2011, y en la que se obvian los orígenes autoritarios de la actual derecha española. ${ }^{12}$

Aparte de las citadas monografías sobre AP, en este caso a nivel estatal, también tenemos que hacer referencia a la existencia de dos obras centradas en el marco autonómico. En el primer caso nos encontramos con el trabajo de Nieves Lagares Diez, en el que analiza el desarrollo del PP de Galicia con el apoyo de una base documental muy extensa. ${ }^{13}$ Para ello la autora también se sumerge en los inicios de AP, aunque como López Nieto y García-Guereta, focaliza su estudio en el análisis de la estructura y organización interna de AP, más que en realizar un estudio sobre la evolución ideológica de los aliancistas en el conjunto, por ejemplo, de los reformismos franquistas, de la derecha franquista o de la extrema derecha neofranquista. Por su parte, el historiador catalán Joan B. Culla, realiza un seguimiento de la derecha española en Cataluña entre 1975 y 2008, fijando

12 Bernardo Rabassa, Historia del Partido Popular (1812-2011). El centro-derecha, 6 vols. (Barcelona: Aracena, 2013). Para el caso de los orígenes de AP destacan los dos primeros volúmenes. En la obra participan miembros de la derecha actual como José Manuel Romay Beccaría, Alicia Sánchez Camacho, Eduardo Zaplana, José Manuel Soria, Antonio Beteta o Ignacio Astarloa.

13 Nieves Lagares Diez, Génesis y desarrollo del Partido Popular de Galicia (Madrid: Tecnos, 1999). 
su estudio en la evolución de AP. ${ }^{14}$ En este caso, el autor realiza un detallado y destacado seguimiento de los aliancistas en el proceso histórico, aunque sin adentrarse en la evolución sobre la crisis del franquismo o el devenir del reformismo franquista o el nacimiento de AP como confluencia de proyectos reformistas institucionales. A pesar de todo nos proporciona una monografía de referencia a la hora de aproximarnos a AP en Cataluña, así como una fuente de análisis sobre las relaciones entre la sede central y la sede catalana de $\mathrm{AP} / \mathrm{PP}$ en un arco cronológico amplio que nos puede ayudar a observar una evolución general sobre el devenir de la derecha española en Cataluña. Asimismo, y a un nivel también de análisis no estatal de la inicial AP, y de carácter militante, nos encontramos un breve estudio enmarcado en una obra colectiva, sobre el nacimiento de AP en Aragón, a manos de Antonio Lacleta Pablo, antiguo procurador en Cortes y uno de los candidatos aliancista en las elecciones de 1977 por la circunscripción de Huesca, y de José Luis Martínez Casado, candidato aliancista por la circunscripción de Zaragoza en las mismas elecciones de 1977.15

En otro nivel de estudios que tiene su núcleo de investigación en AP, destaca la novedosa aportación de Antonia María Ruiz Jiménez sobre la evolución e interpretación del feminismo en la cosmovisión aliancista y del papel de la mujer dentro de las estructuras aliancistas entre $1977 \mathrm{y}$ $2004 .{ }^{16}$ De igual manera es destacable la investigación doctoral inédita de Teresa Sevilla Merino, desde el Derecho, sobre el papel de AP en el proceso constituyente, y que creemos altamente enriquecedora porque recoge de manera pormenorizaba unos debates determinantes para el futuro y supervivencia de la misma plataforma aliancista. ${ }^{17} \mathrm{~A}$ su vez, y aunque se sale del marco cronológico, queremos hacer referencia a dos

14 Joan B. Culla, La dreta espanyola a Catalunya, 1975-2008 (Barcelona: La Campana, 2009).

15 José Luís Casado Martínez, «Aportaciones de Alianza Popular a la Mesa de Partidos» y «Reflexiones políticas sobre la Transición de la derecha aragonesa», en VV.AA., Memoria del Estatuto: Crónica política de la elaboración del Estatuto de Autonomía de Aragón (Zaragoza: Asociación de Exparlamentarios de las Cortes de Aragón, 2002), 211-221 y 443-459; y Antonio LACLETA Pablo, «Historia breve de Alianza Popular de Aragón, 1976-1983", en VV.AA., Memoria del Estatuto, 411-442.

16 Antonia María Ruiz Jiménez, De la necesidad, virtud. La transformación «feminista» del Partido Popular en perspectiva comparada, 1977-2004 (Madrid: CEPC, 2006).

17 Teresa Sevilla Merino, La intervención de Alianza Popular en el proceso constituyente de 1978 (tesis doctoral, Universitat de València, 1988). Asimismo, véase de la misma autora y extraído de su tesis doctoral, «El sistema económico y social defendido por AP en las constituyentes de 1978», en 
estudios iniciales novedosos sobre la integración de AP/PP en el marco europeo: el primero, respecto a la interpretación aliancista sobre la Comunidad Económica Europea y, el segundo, sobre la inclusión de AP/PP como una fuerza integrante más del movimiento conservador europeo del Partido Popular Europeo (PPE).$^{18}$ Finalmente, y en una línea muy similar a las propuestas por López Nieto y García-Guereta en hacer énfasis en la institucionalización de AP, desatacamos una breve aproximación analítica, más concentrada en el PP, realizada por Frédérique Chadel, y que, a pesar de salir de nuestro marco cronológico, nos puede ayudar a complementar, brevemente, desde la politología, una visión del continuum evolutivo de AP/PP.19

Asimismo, a pesar de no ser una monografía, queremos destacar y hacer hincapié en los estudios sobre AP/PP del politólogo José R. Montero, en los cuales se puede observar una síntesis de las mentalidades ideológicas y la evolución de éstas en el electorado aliancista, así como la evolución política de AP desde sus orígenes hasta mediados de los años ochenta, y que nos resultan altamente demostrativos para analizar el devenir de los apoyos electorales procedentes de la extrema derecha que obtuvieron las diferentes manifestaciones electorales de AP hasta $1986 .{ }^{20}$ También tenemos que hacer referencia a un estudio general sobre la evolu-

VV.AA., Estudios en recuerdo de la profesora Sylvia Romeu Alfaro, II (Valencia: Universitat de València, 1989), 953-972.

18 Carlos López Gómez, «Europeísmo y oposición: Alianza Popular y la adhesión de España a la CEE (1976-1985)», Cuadernos de Historia Contemporánea 29 (2007): 279-296; Joan Pere PLAzA I Font, Dinámicas no-lineales en partidos políticos. El caso del Partido Popular Europeo (Barcelona: ICPS, 2007); íd., El proceso de adopción, persistencia y modificación ideológica en los partidos políticos. Análisis del caso del Partido Popular Europeo (1976-1994) (tesis doctoral, Universitat Autònoma de Barcelona, 2009). Asimismo para una versión de los orígenes del PPE, véase, Thomas JANSEN \& Steven van Hecke, At Europe's Service. The Origins and Evolution of the European People's Party (Nueva York/Londres: CES/Springer, 2011).

19 F. Chadel, Penser le changement dans les partis politiques. Le processus d'institutionnalisation au Partido Popular, Working Papers 192 (Barcelona: Institut de Ciències Polítiques i Socials, 2001).

20 Véase José R. MONTERO, «El sub-triunfo de la derecha: Los apoyos electorales de AP-PDP», en Juan J. Linz \& José R. Montero, eds., Crisis y cambio: Electores y partidos en la España de los ochenta (Madrid: CEC, 1986), 345-432; «Los fracasos políticos y electorales de la derecha española: Alianza Popular, 1976-1986», Revista Española de Investigaciones Sociológicas 39 (1987): 7-43; «Los fracasos políticos y electorales de la derecha española: Alianza Popular, 1976-1987», en José F. Tezanos, Ramón CotARElo \& Andrés de Blas, eds., La transición democrática española (Madrid: Sistema, 1989), 495-542. 
ción de AP y de Coalición Democrática (AP; Acción Ciudadana Liberal, liderado por José M. de Areilza; Partido Democrático Progresista, liderado por Alfonso Osorio; Renovación Española, liderado por José Trillo y López Mancisidor; Partido Popular de Cataluña, liderado por Luis Montal Conte y Antonio de Senillosa), que tiene como centro el análisis de los resultados electorales obtenidos en los comicios generales de 1977 y 1979 , respectivamente, a manos del politólogo y sociólogo Rafael López-Pintor. ${ }^{21}$ Por otro lado, y relacionado con los estudios no monográficos sobre AP desde la sociología y la politología, podemos encontrar una gran cantidad de estudios sobre los principales partidos políticos, entre los cuales está referenciado AP, y que nos sirven para aproximarnos de una manera general y complementaria a los mismos inicios y evolución de los aliancistas. En este sentido, entre la gran cantidad de monografías, destacan desde las clásicas de Jorge de Esteban y Luis López Guerra a las más actuales como las de Tania Verge Mestre. ${ }^{22}$ Finalmente, en un sentido también de recopilación sobre el desarrollo en el tiempo de los diferentes partidos estatales, podemos encontrar, también para aproximarnos de una manera muy generalizada, resumida y periodística, diferentes obras en las que, a modo de diccionario político, podemos consultar la evolución de la inicial AP, destacando la excepción del diccionario de partidos políticos editado por Isidre Molas, el cual se sale del parámetro puramente periodístico integrándose por su profusión en el mundo de la politología. ${ }^{23}$

21 Rafael López-Pintor, «Francoist Reformers in Democratic Spain: The Popular Alianza and the Democratic Coalition», en Howard R. Penniman \& Eusebio M. MujaL-León, eds., Spain at the Polls, 1977, 1979, and 1982. A study of the national elections (Durham: Duke University Press, 1985), 188-205.

22 Véase, entre otros, Raúl Morodo et al., Partidos políticos en España (Barcelona: Labor, 1979); Jorge de Esteban \& Luís López Guer Ra, Los partidos políticos en la actual España (Barcelona: Planeta/Instituto de Estudios Económicos, 1982); Michael BusE, La nueva democracia española. Sistema de partidos y orientación del voto (1976-1983) (Madrid: Unión Editorial, 1984); Mario CACIAGLi, Elecciones y partidos políticos en la transición española (Madrid: CIS, 1986); Richard GUNTHER, Giacomo SANI \& Goldie SHABAD, El sistema de partidos políticos en España. Génesis y evolución (Madrid: CIS/ Siglo XXI, 1986); Pilar Gangas Peiró, El desarrollo organizativo de los partidos políticos españoles de implantación nacional (Madrid: Centro de Estudios Avanzados en Ciencias Sociales, 1995); Tania Verge Mestre, Partidos y representación política: las dimensiones del cambio en los partidos políticos españoles, 1976-20o6 (Madrid: CSIC, 2007).

23 A excepción de Isidre Molas, ed., Diccionari dels partits polítics de Catalunya, segle Xx (Barcelona: Enciclopèdia Catalana, 200o), destacamos en el ámbito periodístico, entre otros: Jesús CoN- 
En otro sentido, cabe destacar, en un nivel de investigación no consolidado la existencia de dos trabajos de postgrado de índole predoctoral, altamente útiles para aproximarnos a la intrahistoria de AP. Por un lado, encontramos la investigación de Marie-Evelyne D. Le Poder, la cual hace una aproximación a los inicios de la plataforma aliancista concentrándose en los años 1976-1977 mediante una base documental basada principalmente en la prensa diaria. ${ }^{24} \mathrm{Y}$ por el otro, podemos encontrar otra investigación que tiene su foco de estudio en la evolución de la organización juvenil de AP/PP, Nuevas Generaciones (NNGG), desde sus orígenes hasta los años 200o, de la francesa C. Rayna. ${ }^{25}$ Destaca esta investigación desde la sociología, aparte de por la utilización de una interesante base de fuentes orales, por ser uno de los pioneros, a excepción de la monografía en clave militante sobre el nacimiento y evolución de NNGG, ${ }^{26}$ sobre la organización juvenil aliancista, siendo relevante su análisis sobre las discontinuidades ideológicas en temas como el respeto a la herencia franquista y la autodefinición ideológica. Junto a estos dos trabajos también queremos hacer referencia a la investigadora en formación de la Universidad de Almería, Aurora M. Lorite Checa, la cual ha aportado enriquecedores análisis de la inicial AP y de la extrema derecha neofranquista a nivel autonómico (Andalucía) y provincial (Almería), concretamente. ${ }^{27}$ De igual manera también queremos destacar la existencia de

te Barrera, Los partidos políticos al desnudo (Barcelona: De Gassó Hnos., 1977); Gerardo Duelo, Diccionario de grupos, fuerzas y partidos políticos españoles (Barcelona: La Gaya Ciencia, 1977); Ángel SÁNCHEZ, Diccionario de los partidos políticos (Barcelona: Dopesa, 1977); VV.AA., Un hombre un voto. Guía electoral 1977 (Madrid: Cambio 16, 1977); Javier MoRAL, El centro de la derecha (Madrid: Eudema, 1991).

24 La investigación es fruto de un trabajo realizado inicialmente en francés, llevado a cabo en el marco de los estudios de Lenguas Extranjeras Aplicadas de la Facultad de Letras y Ciencias Humanas de la Universidad Provence Aix-Marseille (Francia), siendo publicado, en forma de ensayo, en Marie Evelyne D. LE Poder, Alianza Popular, 1976-1977 (Vigo: Asociación Cultural de Mondáriz Balneario, 1998).

25 C. RaYNA, «Nouvelles Générations» du Parti Populaire Espagnol. Renouvellement générationnel et idéologique d'un parti, tesina de doctorado (París: L'Institut d'Études Politiques. Sciences Po, 2001).

26 A. Usoz Cazenave \& A. García Prado, 20 años de libertad. NNGG 20 aniversario (Madrid: Nuevas Generaciones del Partido Popular, 1998).

27 Véase, entre otros estudios de la autora Aurora Lorite Checa, «Empresarios, burócratas y familias: los orígenes de Alianza Popular en la transición jienense», en Rafael Quirosa-Cheyrouze, coord., II Congreso Internacional Historia de la Transición en España. Los inicios del proceso demo- 
investigaciones en curso, y actuales, sobre los inicios de AP y su desarrollo, las cuales creemos referenciables como muestra de posibles nuevas fuentes a tener en cuenta en los futuros estudios sobre la derecha española codificada en AP/PP. ${ }^{28}$

Finalmente, encontramos en el ámbito periodístico varias obras que tienen como objeto el desarrollo AP/PP, aunque casi todas ellas se focalizan principalmente en la figura de Manuel Fraga como eje motor interpretativo aliancista. ${ }^{29}$ Por otro lado, destacan dos obras, redactadas al calor del nacimiento de AP, altamente útiles a pesar de su formato periodístico, que nos muestran, básicamente, a través de un especial tratamiento sobre el papel de los siete fundadores de AP, la imagen y aportación política que la plataforma aliancista expelía en esos momentos augurales..$^{30}$ En especial la obra de Rosa Villacastín, la cual recoge entrevistas a los fundadores AP y un resumen de las ponencias del I Congreso Nacional de 1977 de la plataforma aliancista, en un formato marcado por una interpretación pro AP, contraria a la obra de Soledad Gallego y José Luis Martínez, en un formato mucho más crítico. Asimismo, también en el marco periodístico y redactada en los albores augurales de la plataforma aliancista, destaca la obra de Ramón Rodríguez Guerrero en la que podemos observar los inicios de AP en Málaga de una manera altamente

cratizador, CD-ROM (Almería: Servicio de Publicaciones de la Universidad de Almería, 2005); «"Los que quieren para la patria paz, orden y progreso". Conflictos y generaciones políticas en AP durante la transición almeriense», en Fernando ARCAS Cubero \& Cristóbal García Montoro, coords., Andalucía y España. Identidad y conflicto en la historia contemporánea, II (Málaga: Fundación Unicaja, 2008), 473-492. Así como el trabajo inédito de la misma autora La derecha almeriense durante la transición: Alianza Popular (1976-1985), trabajo de investigación de doctorado, Universidad de Almería, 2004.

28 Véase Pablo J. CARr ión SÁnCHEZ, «La reconversión democrática en la derecha: Alianza Popular (1977-1979)» y María de los Ángeles Cor PAS AguirRe, «Alianza Popular (1979-1982): la infructuosa búsqueda de la mayoría natural», ambos en Rafael Quirosa-Cheyrouze, Luis C. NAvarro PÉrez \& Mónica FernándeZ AMAdor, eds., Historia de la Transición en España. Las organizaciones políticas, CD-ROM (Almería: Servicio de Publicaciones de la Universidad de Almería, 2011), 291-304 y $305-318$, respectivamente.

29 Entre otros, véase Fernando Jáuregui, La derecha después de Fraga (Madrid: El País, 1987), y Carlos Dávila \& Luis Herrero: De Fraga a Fraga. Crónica secreta de Alianza Popular (Barcelona: Plaza \& Janés, 1989).

30 José Luis Martínez \& Soledad Gallego, Los 7 magníficos (Madrid: Cambio 16, 1977), y Rosa Villacastín, Alianza Popular: España, lo único importante (Madrid: Maisal, 1977). 
resumida, pero a su vez enriquecedora, y que nos muestra el despliegue de la plataforma aliancista fuera de los núcleos de poder central. ${ }^{31}$

\section{Alianza Popular en los estudios sobre la extrema derecha}

Referente a las investigaciones monográficas sobre AP, tenemos que hacer referencia a los estudios sobre la extrema derecha española. Actualmente, los libros dedicados a la extrema derecha española, desarrollados mediante una metodología científica alejada del periodismo, son pocos. ${ }^{32}$ No obstante, queremos destacar dos libros clave para esta materia: Una patria imaginaria. La extrema derecha española (1973-2005), de Ferran Gallego, ${ }^{33}$ y Reaccionarios y golpistas. La extrema derecha en España: del tardofranquismo a la consolidación de la democracia (1967-1982), de José Luis Rodríguez Jiménez. ${ }^{34}$ Hay otros estudios monográficos sobre la extrema derecha e investigaciones extensas muy destacables, como las de Xavier Casals, ${ }^{35}$ que, a pesar de su importancia para estudiar la extrema derecha española y europea, centran su trabajo exclusivamente en expli-

31 Rafael Rodríguez Guerrero, ¿Quiénes son en Málaga? Alianza Popular (Málaga: Edilafer, 1977).

32 Véase, entre otros, Mariano SÁNCHeZ SolER, Los hijos del 2o-N. Historia violenta del fascismo español (Madrid: Temas de Hoy, 1993); íd., Descenso a los fascismos (Barcelona: Ediciones B, 1998); Manuel Florentín, Guía de la Europa negra. Sesenta años de extrema derecha (Madrid: Anaya y Mario Muchnick, 1994); Joan CANTARERo, La huella de la bota. De los nazis del franquismo a la nueva ultraderecha (Madrid: Temas de Hoy, 2010).

33 Ferran Gallego, Una patria imaginaria. La extrema derecha española (1973-2005) (Madrid: Síntesis, 2005). Asimismo, véase del mismo autor en la misma línea «Nostalgia y modernización. La extrema derecha española ante la crisis del franquismo y la consolidación de la democracia (19731986)», Ayer 71 (2008): 175-209. Y, en el contexto de la transición, del mismo autor: El Mito de la Transición: la crisis del franquismo y los orígenes de la democracia (1973-1977) (Barcelona: Crítica, 2008).

34 José Luis RodRígueZ JimÉnez, Reaccionarios y golpistas. La extrema derecha en España: del tardofranquismo a la consolidación de la democracia (1967-1982) (Madrid: CSIC, 1994). Asimismo, véase del mismo autor en la misma línea, La extrema derecha española en el siglo xx (Madrid: Alianza, 1997), e «Historia de un fracaso y ¿de una refundación?: de la vieja a la nueva extrema derecha en España (1975-2012)», Studia Historia. Historia Contemporánea 30 (2012): 231-268.

35 Entre su extensa bibliografía destacamos sus monografías: Xavier CASALs, Neonazis en España. De las audiciones wagnerianas a los skinheads (1966-1995) (Barcelona: Grijalbo, 1995); La tentación neofascista en España. La evolución de la extrema derecha española durante la transición, así como sus espejos y referentes europeos (Barcelona: Plaza \& Janés, 1998); Ultracatalunya. L'extrema dreta a Catalunya: de l'emergència del búnker al rebuig de les mesquites (1966-2006) (Barcelona: La Esfera de los Libros, 2006). 
car una extrema derecha que no tuvo importancia en el desarrollo político del franquismo, obviando, por otro lado, todo vaso comunicante con el régimen de extrema derecha más importante del momento: el franquismo. En este sentido, creemos que analizar aisladamente a grupos o grupúsculos de extrema derecha ultra residual, como los neonazis de CEDADE (Circulo Español de Amigos de Europa) o del PENS (Partido Español Nacional Socialista), sin englobarlo en el contexto franquista, podría no aportarnos un instrumento de validez global para analizar el desarrollo de la extrema derecha española durante la denominada transición española, a pesar de su más que sobresaliente aportación..$^{36}$

De estas investigaciones, ejes de referencia en la actual historiografía española sobre la extrema derecha, sólo Ferran Gallego apunta a AP como representante de una nueva extrema derecha nacional-populista alejada de la extrema derecha tradicional que podía representar Fuerza Nueva, por ejemplo. En las obras de Rodríguez Jiménez o de Xavier Casals, se considera a la inicial AP como un elemento difícil de definir aunque integrado en una derecha franquista ambigua, alejada de la extrema derecha nacional-populista. Por otro lado, y contrariamente a los postulados del historiador Ferran Gallego, ambos investigadores interpretan inexistente la extrema derecha durante la denominada transición española como consecuencia de no catalogar a AP como una fuerza de representación de una extrema derecha española al solo interpretar a la Alianza Nacional del 18 de Julio como la única representación de la extrema derecha española.

Respecto a los estudios comparativos a nivel europeo sobre la extrema derecha y partiendo de la definición de AP como una fuerza de extrema derecha nacional-populista postfascista de corte postindustrial, son casi inexistentes. ${ }^{37}$ Por un lado, destaca una monografía de P. Matusheck,

36 Asimismo, tal dinámica también la sigue Carles Viñas en su estudio más amplio sobre la transversalidad del movimiento Skinhead en Cataluña, Carles Viñas, Skinheads a Catalunya (Barcelona: Columna, 2004).

37 En el caso de la historiografía española destacan las obras comparativas que aluden la definición de AP como representante de la extrema derecha; véase Xavier CASALs, Ultrapatriotas. Extrema derecha y nacionalismo de la guerra fría a la era de la globalización (Barcelona: Crítica, 2003); José Luis RODRíguez JimÉneZ, ¿Nuevos fascismos? Extrema derecha y neofascismo en Europa y Estados Unidos (Barcelona: Península, 1998); íd., La extrema derecha europea (Madrid: Alianza, 2004). Asimismo existen otras destacadas obras comparativas editadas en España y que recogen los mayores 
la cual creemos insuficiente y que parte de postulados analíticos inexistentes sobre la extrema derecha. En este caso, Matusheck analiza paralelamente los casos de AP/PP y el CDS/PP portugués desde sus orígenes hasta el año $2000 .^{38}$ En otro orden de cosas, es significativo que en los análisis colectivos sobre partidos conservadores o de extrema derecha se incluya raramente el caso de AP, aunque existe una interesante obra colectiva donde se enmarca a AP en los movimientos de extrema derecha nacional-populista postfascista (MSI, NPD o FN, entre otros), a tener en cuenta, y en la que Lourdes López Nieto y Ramón Cotarelo analizan la evolución de AP, a pesar de no ser catalogada directamente como fuerza de extrema derecha nacional-populista. ${ }^{39}$ En contraposición nos encontramos otras investigaciones comparativas focalizadas en los movimientos conservadores europeos, que integran a AP en un difuso movimiento conservador europeo, sin tener en cuenta sus orígenes anclados en parámetros antidemocráticos de la dictadura franquista, como son los estudios de Kenneth Medhurst o los más actuales como los de F. Raniolo.4

especialistas europeos en extrema derecha, que también omiten la idiosincrasia de AP; véase Manuel Pérez Ledesma, comp., Los riesgos para la democracia. Fascismo y neofascismo (Madrid: Pablo Iglesias, 1997); Joan ANTón Mellón, coord., Orden, jerarquía y comunidad. Fascismo, dictaduras y posfascismos en la Europa contemporánea (Madrid: Tecnos, 2002); Xavier CASALs, ed., Political survival on the extreme right. European movements between the inherited past and the need to adapt to the future (Barcelona: ICPS, 2005); Miguel A. Simón, ed., La extrema derecha en Europa desde 1945 hasta nuestros días (Madrid: Tecnos, 2007).

38 Peter Matuschen, Erfolg und Misserfolg konservativer Parteien: die spanische AP-PP und das portugiesische CDS-PP im Vergleich (Wiesbaden: Springer VS, 2008). En la misma línea apunta la comparativa realizada por Maria T. FrAIN \& Howard WiARDA, «Conservative Parties in Democratic Transitions: the Centre-Right in Spain and Portugal», en Frank L. Wilson, ed., The European Center-Right at the End of the Twentieth Century (Londres: Palgrave Publishers Ltd., 1998), 199-224.

39 López Nieto \& Cotarelo, «Spanish Conservatism...». A pesar de esta obra, la mayoría de especialistas internacionales en extrema derecha europea se integran en la línea de no considerar a AP como un representante de la extrema derecha nacional-populista en sus inicios - del tipo MSI o NPD-, así como de considerar la ausencia representativa de una extrema derecha real en España. Acorde con tales postulados, véase entre otros de la extensa bibliografía, aparte de la ya citada anteriormente: Hans Georg BETZ, Radical right-wings populism in Western Europe (Nueva York: St. Martin's Press, 1994); Piero IgNazI, L'estrema destra in Europa (Bolonia: Il Mulino, 1994); íd., Extreme right parties in Western Europe (Oxford: Oxford University Press, 2003); Pierre MiLza, L'Europe en chemise noire. Les extrêmes droites européennes de 1945 á aujourd'hui (París: Fayar, 2002); Cas MuDDE, The Ideology of the Extreme Right (Manchester University Press, 2002); Pippa NorRIs, Derecha radical. Votantes y partidos políticos en el mercado electoral (Madrid: Akal, 2009).

40 Kenneth Medhurst, «Spanish Conservative Politics», en Zig Layton-Henry, ed., Conservative Politics in Western Europe (Londres: Macmillan Press, 1982), 292-317; y Francesco RAniolo, I ParFRANQUISME \& TRANSICIÓ 3 (2015) ISSN 2014-511X PUNCTUM, UNIVERSITAT OBERTA DE CATALUNYA \& FUNDACIÓ CARLES PII SUNYER 


\section{Alianza Popular en los estudios sobre la derecha española: actualidad y futuro}

Siguiendo la dinámica de analizar la incursión de AP en los estudios más generales de la historiografía española, también creemos necesario sacar a colación las investigaciones monográficas sobre la evolución de la derecha española. En este sentido, son pocos los estudios, destacando por encima de ellos la producción de Pedro Carlos González Cuevas, a pesar de no aportar nuevos parámetros analíticos en la categorización de AP. ${ }^{41}$ Todo y así, son destacables sus investigaciones sobre la derecha española, siendo, además, uno de los principales investigadores sobre el pensamiento político de uno de los fundadores de la plataforma aliancista: Gonzalo Fernández de la Mora..$^{42}$ Por otro lado, desde unos parámetros ideológicos e interpretativos englobados en el conservadurismo político, encontramos las obras de Ricardo de la Cierva y José María García Escudero sobre los orígenes de la derecha española y su evolución. ${ }^{43}$ Mientras la obra de R. de la Cierva, La Derecha sin remedio, constituye un análisis del movimiento conservador español, en un formato periodístico que comprende una cronología entre 1801-1987, la obra de García Escudero, Vista a la derecha, se concentra en analizar figuras representativas de la derecha española contemporánea (Cánovas, Maura, Cambó,

titi conservatori in Europa Occidentale (Bolonia: Il Mulino, 200o). En otras obras, se interpreta a la Unión de Centro Democrático (UCD) como el principal partido conservador español por encima de AP, véase Roger Morgan \& Stefano Silvestri, eds., Moderates and Conservatives Parties in Western Europe: political parties, the European Community, and the Atlantic Alliance (Londres: Heinemann Educational, 1982).

41 Entre las monografías de Pedro Carlos González Cuevas sobre la derecha española destacan las obras Historia de las derechas españolas. De la Ilustración a nuestros días (Madrid: Biblioteca Nueva, 2000) y El pensamiento político de la derecha española en el siglo XX. De la crisis de la restauración al Estado de partidos (1898-200o) (Madrid: Tecnos, 2005).

42 Pedro Carlos González Cuevas, «Gonzalo Fernández de la Mora y la legitimación del franquismo», Sistema 91 (1989): 83-105; Conservadurismo heterodoxo. Tres vías ante las derechas españolas: Maurice Barrès, José Ortega y Gasset y Gonzalo Fernández de la Mora (Madrid: Biblioteca Nueva, 2009); «Ortega y Gasset en la obra de Gonzalo Fernández de la Mora», en Antonio Cañellas, coord., Conservadores y tradicionalistas en la España del siglo XX (Gijón: Trea, 2012), 227-260.

43 Ricardo de la Cierva, La derecha sin remedio (1801-1987). De la prisión de Jovellanos al martirio de Fraga (Barcelona: Plaza \& Janés, 1987), y José María García Escudero, Vista a la derecha (Madrid: Rialp, 1988). 
Gil Robles, López Rodó y Fraga). De igual manera, no podemos olvidar otros estudios sobre la derecha contemporánea española que, a pesar de ser destacados para comprender la evolución de la derecha española y sus diferentes manifestaciones a lo largo del tiempo, y a pesar que no llegan a analizar AP, tienden por lo ambicioso en el tiempo de la obra a un totum revolutum que mezcla partidos, personajes, régimen o instituciones sin que haya a veces una línea de continuidad clara, lo cual puede ser complicado si nos aproximamos inicialmente al estudio de la derecha española contemporánea. ${ }^{4}$ En contraposición podemos encontrar otros estudios colectivos sobre el devenir de la derecha española contemporánea mejor delimitados y con una profusión en las diferentes manifestaciones del movimiento conservador español, aunque sin que se haga una mención especial al caso de AP. En este caso encontramos las obras colectivas coordinadas por Javier Tusell o Antonio Cañellas, en la que varios autores analizan las diversas expresiones y manifestaciones de la derecha española a lo largo del siglo xx sin aproximarse al caso de AP.45 En una dinámica similar, en este caso dentro de una publicación periódica, queremos destacar un dossier dirigido por Fernando del Rey para la revista Historia y Política que recoge los estudios de varios especialistas sobre la derecha española actual (Ferran Gallego, Pedro Carlos González Cuevas, Charles T. Powell o Feliciano Montero, entre otros), donde se realizan análisis de las diferentes manifestaciones de la derecha española desde la integrista a la tecnocratista pasando por la reformista franquista, así como sus relaciones con el mundo europeo, el catolicismo o los intelectuales. ${ }^{46}$

Finalmente queremos destacar una obra redactada por el historiador José Antonio Piqueras que creemos altamente enriquecedora, tanto por su metodología como por su estudio, para comprender la evolución de la derecha española. La investigación parte de la figura de Cánovas del

44 Paul Preston, Las derechas españolas en el siglo xx: autoritarismo, fascismo y golpismo (Madrid: Sistema, 1986).

45 Javier Tusell, Feliciano Montero \& José María Marín, eds., Las derechas en la España contemporánea (Barcelona: Anthropos/UNED, 1997); y CAÑELLAs, Conservadores y tradicionalistas...

46 Fernando del Rey, coord., «Las derechas: tecnócratas, liberales y neocons», Historia y Política 18 (2007). 
Castillo a la par que indaga la influencia del político conservador decimonónico en el pensamiento y evolución de la derecha española hasta 2004, fecha en que el PP perdió el poder. Destaca también la definición sobre Fraga y AP como representantes de la «derecha transfranquista».47

Junto a todo ello, no queremos dejar de mencionar una obra de carácter militante, que no por ello deja de ser una fuente a tener en cuenta sobre el significado político y social de la derecha española codificada en la plataforma aliancista analizada. La obra en cuestión, de Juan Ramón Calero (dirigente aliancista de Murcia), titulada La construcción de la derecha española y escrita en los años ochenta, realiza una reflexión sobre la deriva de la derecha en aquel momento y sus necesidades futuras. ${ }^{48} \mathrm{En}$ este sentido, hacía hincapié en la necesidad de que la derecha política dejase de concebir el partido como plataforma electoral individualista para transformarse en un partido institucionalizado y de masas, que pudiera sobrevivir y superar las típicas estructuras tradicionales de los partidos de cuadros de derechas basados en la lucha por el poder y la concepción patrimonial del partido por parte del jefe. Destaca su crítica a los fracasos de la derecha política (Unión de Centro Democrático - UCD - y AP) como consecuencia de la concepción sobre el partido como organización de cuadros patrimonializados y como simples plataformas personalistas. A su vez se postulaba por la necesidad que la derecha se reivindicase políticamente sobre el cristianismo, el liberalismo, la libertad y el reformismo, todo ello asumiendo la concepción de término derecha alejado de cualquier interpretación peyorativa.

En un sentido, también de reflexión sobre la evolución de la derecha española y su actual representación, destaca la obra de J.A. González Casanova, La derecha contra el Estado, en la que el autor reflexiona sobre

47 José Antonio Piqueras, Cánovas y la derecha española. Del magnicidio a los neocon (Barcelona: Península, 2008). Asimismo, la búsqueda de las raíces de la actual derecha española en personalidades de los siglos xıx y xx, aparte de la obra de José María García Escudero (Vista a la derecha), también se pueden consultar en diferentes formatos, entre otros: Manuel FraGA, El pensamiento conservador español (Barcelona: Planeta, 1981); Javier TusEll \& Juan AvilÉs, La derecha contemporánea. Sus orígenes: el maurismo (Madrid: Espasa-Calpe, 1986), o Pedro Carlos GonZÁlez Cuevas, El pensamiento conservador español: ideas políticas de Maeztu, Maurras y Schmitt (Madrid: Biblioteca Nueva Madrid, 2007).

48 Juan Ramón Calero, La construcción de la derecha española (Murcia: Prócer, 1985). 
la diferencia de la actual derecha española respecto a sus homólogos europeos como consecuencia de su tradición autoritaria y antidemocrática, y sus dificultades a la hora de interiorizar el régimen democrático como sistema irreversible. ${ }^{49}$ Asimismo, también queremos destacar la reflexión realizada por el investigador Sebastián Balfour sobre la derecha actual representada en el PP y la concepción del término nación, una reflexión que, a pesar de salir de nuestro marco cronológico, creemos que es enriquecedora para complementar el esquema interpretativo de la actual derecha española. ${ }^{\circ}$ Para acabar, ya en otros niveles, se encontrarían diversas reflexiones sobre la actual derecha española y sus manifestaciones, que irían desde obras escritas desde la misma militancia, la simpatía o la crítica, en algunos casos, a otras caracterizadas por englobar una amalgama periodística de diferentes índoles. ${ }^{51}$

Finalmente, como últimas investigaciones novedosas de historiadores, queremos destacar la reciente aportación en portugués de Carme Molinero, la cual hace un excelente análisis sobre el nacimiento y desarrollo de la actual derecha española, concentrándose en AP, en el periodo de la transición española, ${ }^{52}$ así como la aportación de Charles T. Powell, la cual, a pesar de no aportar ninguna novedad en el terreno interpretativo

49 José Antonio González CaSAnova, La derecha contra el Estado. El liberalismo autoritario en España (1833-2008) (Lleida: Milenio, 2009).

50 Sebastian BALFOU R, «La derecha política y la idea de nación», en Manuel OrTiz Heras, coord., Culturas políticas del nacionalismo español. Del franquismo a la transición (Madrid: Los Libros de la Catarata, 2009), 59-71; también véase del mismo autor «The Reinvention of the Spanish Conservatism: the Popular Party since 1989", en Sebastian BALfour, ed., The Politics of Contemporary in Spain (Londres y Nueva York: Routledge, 2005), 146-168.

51 Véase, entre otros, Tom Burns Marañón, Conversaciones sobre la derecha (Barcelona: Plaza \& Janés, 1997); Gustavo BuENo, El mito de la derecha: una visión crítica de la derecha en España (Madrid: Temas de Hoy, 2008); Carlos Tалво, Neoliberales, neoconservadores, aznarianos. Ensayos sobre el pensamiento de la derecha lenguaraz (Madrid: Los Libros de la Catarata, 2008). Así como en un nivel más memorístico y programático, José María AzNAR, La segunda transición (Madrid: Espasa-Calpe, 1994); íd., Retratos y perfiles: de Fraga a Bush (Barcelona: Planeta, 2005); íd., Memorias I (Barcelona: Planeta, 2012); Alfonso Osorio, Escrito desde la derecha. Canto a la libertad (Barcelona: Plaza \& Janés, 1985); Alejo VIDAL-QuAdRAs, La derecha. Un intento de destilación axiológica (Barcelona: Destino, 1997).

52 Carme Molinero, «A herança do passado. O franquismo e a direita espanhola», en Manuel Loff, Filipe Piedade \& Luciana Castro Soutelo, coords., Ditadura e Revolução. Democracia e políticas da memoria (Coimbra: Almedina, 2015), 307-330. Destaca del presente análisis la adopción del término «extrema derecha nacional-populista» para referirse a la inicial AP. 
tradicional de AP, presenta un destacado resumen sobre la evolución de AP hasta 1982.53 Por otro lado, destaca la reciente obra de Julio Gil Pecharromán, el cual hace un seguimiento del partido único del franquismo (FET-JONS/Movimiento Nacional) desde sus inicios en 1937 hasta 1977, haciendo un especial hincapié en el proceso de formación de AP como proyecto de confluencia de diversas agrupaciones políticas nacidas al calor del asociacionismo franquista. ${ }^{54}$

Como punto final queremos remarcar que, partiendo de la buena salud que gozan en la historiografía española los estudios sobre la transición y el tardofranquismo, creemos necesario alentar los estudios sobre los orígenes de la actual derecha española. En el campo de AP queda aún mucho recorrido, especialmente a nivel autonómico y local. Los estudios locales sobre la estructuración inicial de AP nos pueden ayudar a mejorar y a configurar el mapa inicial de la plataforma neofranquista, pudiéndose dar especial hincapié a los orígenes políticos y sociales de los notables, militantes y simpatizantes locales de AP, así como su vinculación orgánica con la cúpula central. Asimismo, sería necesario que esos estudios fueran completados —o al compás—de análisis más complejos sobre la evolución de UCD y de la extrema derecha neofranquista ortodoxa (Fuerza Nueva, FE-JONS, entre otros) con el objetivo de tratar de triangularlos conjuntamente con la inicial AP. Todo ello nos ayudaría a analizar y comprender los vasos comunicantes existentes en la evolución y estructuración de la actual derecha española, sin dejar de desatender con ello, por otro lado, otro campo complementario como sería la evolución de las relaciones con los movimientos homólogos europeos.

\section{Conclusiones}

A modo de conclusión no queremos dejar pasar la ocasión para poner de manifiesto que el carácter de la lealtad a la obra de Franco y a la legitimi-

53 Charles T. PowelL, «Alianza Popular y la Transición: la difícil forja de una derecha democrática española», en Rafael Quirosa-Cheyrouze, ed., Los partidos en la Transición. Las organizaciones políticas en la construcción de la democracia española (Madrid: Biblioteca Nueva, 2013), 163-183.

54 Julio Gil Pechar román, El Movimiento Nacional (1937-1977). Del Partido Único a Alianza Popular (Barcelona: Planeta, 2013). 
dad continuada del franquismo, y la negativa a abrir un periodo constituyente que llegara a deslegitimar la dictadura y a establecer, como valores propios de la España constitucional, los de la democracia vigente en la Europa posterior a la Segunda Guerra Mundial, son la clave para determinar a la naciente Alianza Popular como una plataforma de extrema derecha neofranquista de carácter nacional-populista en sus inicios.

Asimismo, las características esenciales de la cultura política de la derecha española en el periodo de la democracia no son comprensibles sin tener en cuenta ese origen que combina reforma y resistencia del ideario franquista. Por poner un solo ejemplo: la consideración de que la democracia es el resultado de la evolución económica, social e incluso política del franquismo, es un factor distintivo de la derecha española, que la hace dilatadamente equiparable, en los rasgos más profundos de su cultura política, a una derecha europea salida directamente de la destrucción del fascismo. En este sentido, el origen de la actual derecha española, nacida de un régimen de extrema derecha de origen fascista (el franquismo) - vertebrada especialmente a partir de 1982 tras la implosión de UCD y unificada a partir de 1989 en el PP-, nos debería ayudar a interpretar el porqué de una derecha anómala en comparación de la europea originada después de la Segunda Guerra Mundial bajo el mito del antifascismo.

\section{Bibliografía}

ALGACY, Joseph. 1989. L'extrême droite en France (1965 a 1984). París: L'Harmattan. ANTón MELlón, Joan, coord. 2002. Orden, jerarquía y comunidad. Fascismo, dictaduras y posfascismos en la Europa contemporánea. Madrid: Tecnos.

AznAR, José María. 1994. La segunda transición. Madrid: Espasa-Calpe.

- 2005. Retratos y perfiles: de Fraga a Bush. Barcelona: Planeta. . 2012. Memorias I. Barcelona: Planeta.

BALfour, Sebastian. 2005. «The Reinvention of the Spanish Conservatism: the Popular Party since 1989». En Sebastian BALFOUR, ed. The Politics of Contemporary in Spain, 146-168. Londres/Nueva York: Routledge.

- 2009. «La derecha política y la idea de nación». En Manuel OrTiz Heras, coord. Culturas políticas del nacionalismo español. Del franquismo a la transición, 59-71. Madrid: Los Libros de la Catarata. 
BAón, Rogelio. 2001. Historia del Partido Popular I. Del Franquismo a la Refundación. Madrid: Ibersaf.

BETZ, Hans-George. 1994. Radical right-wings populism in Western Europe. Nueva York: St. Martin's Press.

Bueno, Gustavo. 2008. El mito de la derecha: una visión crítica de la derecha en España. Madrid: Temas de Hoy.

Burns Marañón, Tom. 1997. Conversaciones sobre la derecha. Barcelona: Plaza \& Janés.

BusE, Michael. 1984. La nueva democracia española. Sistema de partidos y orientación del voto (1976-1983). Madrid: Unión Editorial.

CACIAGLI, Mario. 1986. Elecciones y partidos políticos en la transición española. Madrid: CIS.

Calero, Juan Ramón. 1985. La construcción de la derecha española. Murcia: Prócer.

CANTARERO, Joan. 2010. La huella de la bota. De los nazis del franquismo a la nueva ultraderecha. Madrid: Temas de Hoy.

CAÑELLAS, Antonio, coord. 2012. Conservadores y tradicionalistas en la España del siglo $X X$. Gijón: Trea.

CAR RIón SÁnchez, Pablo J. 2011. «La reconversión democrática en la derecha: Alianza Popular (1977-1979)». En Rafael Quirosa-Cheyrouze et al., ed. Historia de la Transición en España. Las organizaciones políticas, 291-304. CD-ROM. Almería: Servicio de Publicaciones de la Universidad de Almería.

Casado Martínez, José Luis. 2002. «Aportaciones de Alianza Popular a la Mesa de Partidos y Reflexiones políticas sobre la Transición de la derecha aragonesa». En VV.AA. Memoria del Estatuto: Crónica política de la elaboración del Estatuto de Autonomía de Aragón, 211-221 y 443-459. Zaragoza: Asociación de Extraparlamentarios de las Cortes de Aragón.

CASAls, Xavier. 1995. Neonazis en España. De las audiciones wagnerianas a los skinheads (1966-1995). Barcelona: Grijalbo.

-1998. La tentación neofascista en España. La evolución de la extrema derecha española durante la transición, así como sus espejos y referentes europeos. Barcelona: Plaza \& Janés.

- 2003. Ultrapatriotas. Extrema derecha y nacionalismo de la guerra fría a la era de la globalización. Barcelona: Crítica.

- ed. 2005. Political survival on the extreme right. European movements between the inherited past and the need to adapt to the future. Barcelona: ICPS.

- 2006. Ultracatalunya. L'extrema dreta a Catalunya: de l'emergència del búnker al rebuig de les mesquites (1966-2006). Barcelona: La Esfera de los Libros.

CHADEL, F. 2001. Penser le changement dans les partis politiques. Le processus d'institutionnalisation au Partido Popular. Working Papers 192. Barcelona: Institut de Ciències Polítiques i Socials.

Cierva, Ricardo de la. 1987. La derecha sin remedio (1801-1987). De la prisión de Jovellanos al martirio de Fraga. Barcelona: Plaza \& Janés.

Conte BARrera, Jesús. 1977. Los partidos políticos al desnudo. Barcelona: De Gassó Hnos. 
Corpas Aguir re, María de los Ángeles. 2011. «Alianza Popular (1979-1982): la infructuosa búsqueda de la mayoría natural». En Rafael Quirosa-CHEYrouze, Luis C. Navar ro Pérez \& Mónica Fernández Amador, eds. Historia de la Transición en España. Las organizaciones políticas, 305-318. CD-ROM. Almería: Servicio de Publicaciones de la Universidad de Almería.

Culla, Joan B. 2009. La dreta espanyola a Catalunya, 1975-20o8. Barcelona: La Campana.

Dávila, Carlos \& Luis Herrero. 1989. De Fraga a Fraga. Crónica secreta de Alianza Popular. Barcelona: Plaza \& Janés.

Duelo, Gerardo. 1977. Diccionario de grupos, fuerzas y partidos políticos españoles. Barcelona: La Gaya Ciencia.

ELOR Riaga, Gabriel. 2008. El camino de la concordia. De la cárcel al Parlamento. Barcelona: Debate.

Esteban, Jorge de \& Luis López Guerra. 1982. Los partidos políticos en la actual España. Barcelona: Planeta/Instituto de Estudios Económicos.

FERnÁndeZ de La Mora, Gonzalo. 1995. Río arriba. Memorias. Barcelona: Planeta.

Florentín, Manuel. 1994. Guía de la Europa negra. Sesenta años de extrema derecha. Madrid: Anaya/Mario Muchnick.

Fraga Iribarne, Manuel. 1977. Alianza Popular. Bilbao: Albia.

-1981. El pensamiento conservador español. Barcelona: Planeta.

.1987. En busca del tiempo perdido. Barcelona: Planeta.

Frain, Maria T. \& Howard Wiarda. 1998. «Conservative Parties in Democratic Transitions: the Centre-Right in Spain and Portugal». En Frank L. Wilson, ed. The European Centre-Right at the End of the Twentieth Century, 199-224. Londres: Palgrave Publishers Ltd.

Fuente, Licinio de la. 1998. Valió la pena. Madrid: Edaf.

Gallego, Ferran. 2002. Por qué Le Pen. Barcelona: Ediciones de Intervención Cultural.

- 2004. Neofascistas. Democracia y extrema derecha en Francia e Italia. Barcelona: Plaza \& Janés.

- 2005. De Auschwitz a Berlín. Alemania y la extrema derecha, 1945-2004. Barcelona: Plaza \& Janés.

- 2005. Una patria imaginaria. La extrema derecha española (1973-2005). Madrid: Síntesis.

- 2008. El Mito de la Transición: la crisis del franquismo y los orígenes de la democracia (1973-1977). Barcelona: Crítica, 2008.

— 2008. «Nostalgia y modernización. La extrema derecha española ante la crisis del franquismo y la consolidación de la democracia (1973-1986)». Ayer 71: 175-209.

_. 2012. «El MSI y el lugar del fascismo en la cultura política italiana». Studia Storica. Historia Contemporánea 30: 173-204.

Gangas PeIró, Pilar. 1995. El desarrollo organizativo de los partidos políticos españoles de implantación nacional. Madrid: Centro de Estudios Avanzados en Ciencias Sociales.

García Escudero, José María. 1988. Vista a la derecha. Madrid: Rialp. 
García-Guereta Rodríguez, Elena María. 2001. Factores externos e internos en la transformación de los partidos políticos. El caso de AP/PP. Madrid: Centro de Estudios Avanzados en Ciencias Sociales.

Gil Pechar román, Julio. 2013. El Movimiento Nacional (1937-1977). Del Partido Único a Alianza Popular. Barcelona: Planeta.

GonzÁlez Casanova, José Antonio. 2009. La derecha contra el Estado. El liberalismo autoritario en España (1833-20o8). Lleida: Milenio.

González Cuevas, Pedro Carlos. 1989. «Gonzalo Fernández de la Mora y la legitimación del franquismo». Sistema 91: 83-105.

- 2000. Historia de las derechas españolas. De la Ilustración a nuestros días. Madrid: Biblioteca Nueva.

- 2005. El pensamiento político de la derecha española en el siglo Xx. De la crisis de la restauración al Estado de partidos (1898-200o). Madrid: Tecnos.

- 2007. El pensamiento conservador español: ideas políticas de Maeztu, Maurras y Schmitt. Madrid: Biblioteca Nueva Madrid.

- 2009. Conservadurismo heterodoxo. Tres vías ante las derechas españolas: Maurice Barrès, José Ortega y Gasset y Gonzalo Fernández de la Mora. Madrid: Biblioteca Nueva.

- . 2012. «Ortega y Gasset en la obra de Gonzalo Fernández de la Mora». En Antonio CAÑ ELLAS, coord. Conservadores y tradicionalistas en la España del siglo XX, 227-26o. Gijón: Trea.

GunTHER, Richard; Giacomo SANi \& Goldie SHABAD. 1986. El sistema de partidos políticos en España. Génesis y evolución. Madrid: CIS/Siglo XXI.

IGNAZI, Piero. 1989. Il polo escluso. Profilo del Movimento Sociale Italiano. Bolonia: Il Mulino.

-1994. L'estrema destra in Europa. Bolonia: Il Mulino.

- 2003. Extreme right parties in Western Europe. Oxford: Oxford University Press.

Jansen, Thomas \& Steven van Hecke. 2011. At Europe's Service. The Origins and Evolution of the European People's Party. Nueva York/Londres: CES/Springer.

Jauregui, Fernando. 1987. La derecha después de Fraga. Madrid: El País.

LaCleta Pablo, Antonio. 2002. «Historia breve de Alianza Popular de Aragón, 19761983». En VV.AA. Memoria del Estatuto: Crónica política de la elaboración del Estatuto de Autonomía de Aragón, 411-442. Zaragoza: Asociación de Exparlamentarios de las Cortes de Aragón.

Lagares Diez, Nieves. 1999. Génesis y desarrollo del Partido Popular de Galicia. Madrid: Tecnos.

LE Poder, Marie Evelyne D. 1998. Alianza Popular, 1976-1977. Vigo: Asociación Cultural de Mondáriz Balneario.

López Gómez, Carlos. 2007. «Europeísmo y oposición: Alianza Popular y la adhesión de España a la CEE (1976-1985)». Cuadernos de Historia Contemporánea 29: 279-296.

López Nieto, Lourdes. 1988. Alianza Popular: Estructura y evolución electoral de un partido conservador (1976-1982). Madrid: CIS. 
López Nieto, Lourdes. 1995. «El centro-derecha en España, 1976-1982». En Lourdes López Nieto, Richard Gillespie \& Michael Waller, eds. Política faccionaly democratización, 51-66. Madrid: CEC.

- 1999. «La constitución de un partido abierto: Alianza Popular/Partido Popular». En Juan Carlos Monedero \& Juan Luís Paniagua Soto, coords. En torno a la democracia en España. Temas abiertos del sistema político español, 233-254. Madrid: Tecnos.

- 2009. «20 años de Partido Popular. Del aislamiento al liderazgo». Cuadernos de pensamiento político. FAES 21: 175-198.

López Nieto, Lourdes \& Ramón CotaRelo. 1988. «Spanish Conservatism, 1976-1987». En Klaus von Beyme, ed., Right-wing Extremism in Western Europe, 80-95. Londres: Frank Cass \& Co. Ltd.

López-Pintor, Rafael. 1985. «Francoist Reformers in Democratic Spain: The Popular Alianza and the Democratic Coalition». En Howard R. Penniman \& Eusebio M. MuJAL-LEón, eds. Spain at the Polls, 1977, 1979, and 1982. A study of the national elections, 188-205. Durham: Duke University Press.

López Rodó, Laureano. 1993. Claves de la Transición. Memorias IV. Barcelona: Plaza \& Janés.

LoRite CheCA, Aurora. 2004. La derecha almeriense durante la transición: Alianza Popular (1976-1985). Trabajo de investigación de doctorado. Universidad de Almería.

- 2005. «Empresarios, burócratas y familias: los orígenes de Alianza Popular en la transición jienense». En Rafael Quirosa-CHEYrouze, coord. II Congreso Internacional Historia de la Transición en España. Los inicios del proceso democratizador. CD-ROM. Almería: Servicio de Publicaciones de la Universidad de Almería.

. 2008. «Los que quieren para la patria paz, orden y progreso. Conflictos y generaciones políticas en AP durante la transición almeriense». En Fernando ARCAS Cubero \& Cristóbal García Montoro, coords. Andalucía y España. Identidady conflicto en la historia contemporánea, II, 473-492. Málaga: Fundación Unicaja.

Martínez, José Luis \& Soledad Gallego. 1977. Los 7 magníficos. Madrid: Cambio 16.

MAtusCHeк, Peter. 2008. Erfolg und Misserfolg konservativer Parteien: die spanische APPP und das portugiesische CDS-PP im Vergleich. Wiesbaden: Springer VS.

Medhurst, Kenneth. 1982. «Spanish Conservative Politics». En Zig Layton-Henry, ed. Conservative Politics in Western Europe, 292-317. Londres: Macmillan Press.

MilzA, Pierre. 2002. L'Europe en chemise noire. Les extrêmes droites européennes de 1945 á aujourd'hui. París: Fayar.

Minkenberg, Michael. 1992. «The New Right in Germany. The transformation of conservatism and extreme right». European Journal of Political Research 22: 55-81.

Molas, Isidre, ed. 200o. Diccionari dels partits polítics de Catalunya, segle XX. Barcelona: Enciclopèdia Catalana.

Molinero, Carme. 2015. «A herança do passado. O franquismo e a direita espanhola». En Manuel Loff, Filipe Piedade \& Luciana Castro Soutelo, coords. Ditadura e Revolução. Democracia e políticas da memoria, 307-330. Coimbra: Almedina. 
Montero, José R. 1986. «El sub-triunfo de la derecha: Los apoyos electorales de AP-PDP». En Juan J. Linz \& José R. MonTERo, eds. Crisis y cambio: Electores y partidos en la España de los ochenta, 345-432. Madrid: CEC.

— 1987. «Los fracasos políticos y electorales de la derecha española: Alianza Popular, 1976-1986». Revista Española de Investigaciones Sociológicas 39: 7-43. . 1989. «Los fracasos políticos y electorales de la derecha española: Alianza Popular, 1976-1987». En José F. Tezanos, Ramón Cotarelo \& Andrés DE Blas, eds. La transición democrática española, 495-542. Madrid: Sistema.

MORAL, Javier. 1991. El centro de la derecha. Madrid: Eudema.

Moreau, Patrick. 1994. Les héritiers di III Reich. L'extrême droite allemande de 1945 à nos jours. París: Seuil.

Morgan, Roger \& Stefano SIlvestri, eds. 1982. Moderates and Conservatives Parties in Western Europe: political parties, the European Community, and the Atlantic Alliance. Londres: Heinemann Educational.

Morodo, Raúl et al. 1979. Partidos políticos en España. Barcelona: Labor.

MudDE, Cas. 2002. The Ideology of the Extreme Right. Manchester University Press.

Nor RIS, Pippa. 2009. Derecha radical. Votantes y partidos politicos en el mercado electoral. Madrid: Akal.

Osorio, Alfonso. 1985. Escrito desde la derecha. Canto a la libertad. Barcelona: Plaza \& Janés.

- 2000. De orilla a orilla. Barcelona: Plaza \& Janés.

Penella, Manuel. 2005. Los orígenes y la evolución del Partido Popular. Una historia de AP (1973-1989). 2 vols. Salamanca: Caja Duero.

PÉrez EsCOLAR, Rafael. 2005. Memorias. Madrid: Foca.

Pérez Ledesma, Manuel, comp. 1997. Los riegos para la democracia. Fascismo y neofascismo. Madrid: Pablo Iglesias.

Piqueras, José Antonio. 2008. Cánovas y la derecha española. Del magnicidio a los neocon. Barcelona: Península.

Plaza I Font, Joan Pere. 2007. Dinámicas no-lineales en partidos políticos. El caso del Partido Popular Europeo. Barcelona: ICPS.

- 2009. El proceso de adopción, persistencia y modificación ideológica en los partidos políticos. Análisis del caso del Partido Popular Europeo (1976-1994). Tesis doctoral. Universitat Autònoma de Barcelona.

Powell, Charles T. 2013. «Alianza Popular y la Transición: la difícil forja de una derecha democrática española». En Rafael Quirosa-Cheyrouze, ed. Los partidos en la Transición. Las organizaciones políticas en la construcción de la democracia española, 163-183. Madrid: Biblioteca Nueva.

Preston, Paul. 1986. Las derechas españolas en el siglo xx: autoritarismo, fascismo y golpismo. Madrid: Sistema.

RABASSA, Bernardo. 2013. Historia del Partido Popular (1812-2011). El centro-derecha. 6 vols. Barcelona: Aracena.

RANiolo, Francesco. 2000. I Partiti conservatori in Europa Occidentale. Bolonia: Il Mulino. 
Rayna, C. 2001. "Nouvelles Générations» du Parti Populaire Espagnol. Renouvellement générationnel et idéologique d'un parti. Tesina de doctorado. París: L'Institut d'Études Politiques. Sciences Po.

REY, Fernando del, coord. 2007. Las derechas: tecnócratas, liberales y neocons. Historia y Politica 18.

Río, Miguel A. del. 2013. De la extrema derecha neofranquista a la derecha conservadora. Los orígenes de Alianza Popular, 1973-1979. Tesis doctoral. Universitat Autònoma de Barcelona.

Robles Piquer, Carlos. 2011. Memoria de cuatro Españas. República, franquismo y democracia. Barcelona: Planeta.

Rodríguez Guerrero, Rafael. 1977. ¿Quiénes son en Málaga? Alianza Popular. Málaga: Edilafer.

RODRÍGUEZ JIMÉNEZ, José Luis. 1994. Reaccionarios y golpistas. La extrema derecha en España: del tardofranquismo a la consolidación de la democracia (1967-1982). Madrid: CSIC.

-1997. La extrema derecha española en el siglo Xx. Madrid: Alianza.

-1998. ¿Nuevos fascismos? Extrema derecha y neofascismo en Europa y Estados Unidos. Barcelona: Península.

- 2004. La extrema derecha europea. Madrid: Alianza.

- 2012. «Historia de un fracaso y ¿de una refundación?: de la vieja a la nueva extrema derecha en España (1975-2012)». Studia Historia. Historia Contemporánea 30: $231-268$.

Ruiz JimÉnEZ, Antonia María. 2006. De la necesidad, virtud. La transformación «feminista» del Partido Popular en perspectiva comparada, 1977-2004. Madrid: CEPC.

Ruiz Martínez, José C. 1981. Mi lucha por un partido: Alianza Popular. Alicante: Gráficas Díaz.

SÁNCHEZ, Ángel. 1977. Diccionario de los partidos políticos. Barcelona: Dopesa.

SÁNCHEZ Soler, Mariano. 1993. Los hijos del 2O-N. Historia violenta del fascismo español. Madrid: Temas de Hoy.

-1998. Descenso a los fascismos. Barcelona: Ediciones B.

Sevilla Merino, Teresa. 1988. La intervención de Alianza Popular en el proceso constituyente de 1978. Tesis doctoral. Universitat de València.

-1989. «El sistema económico y social defendido por AP en las constituyentes de 1978». En VV.AA. Estudios en recuerdo de la profesora Sylvia Romeu Alfaro, II, 953-972. Valencia: Universitat de València.

Silva MUÑoz, Federico. 1993. Memorias políticas. Barcelona: Planeta.

Simón, Miguel A., ed. 2007. La extrema derecha en Europa desde 1945 hasta nuestros días. Madrid: Tecnos.

Tалво, Carlos. 2008. Neoliberales, neoconservadores, aznarianos. Ensayos sobre el pensamiento de la derecha lenguaraz. Madrid: Los Libros de la Catarata.

TARCHI, Marco. 1997. Dal MSI ad AN: organizzazione e strategie. Bolonia: Il Mulino.

TuSELl, Javier \& Juan AviLÉs. 1986. La derecha contemporánea. Sus orígenes: el maurismo. Madrid: Espasa-Calpe. 
TuSEll, Javier; Feliciano Montero \& José M. MARín, eds. 1997. Las derechas en la España contemporánea. Barcelona: Anthropos/UNED.

Usoz Cazenave, A. \& A. García Prado. 1998. 20 años de libertad. NNGG 20 aniversario. Madrid: Nuevas Generaciones del Partido Popular.

Velo de Antelo, José María. 2010. De ayer a hoy. Los orígenes del Partido Popular. Madrid: Galland Books.

Verge Mestre, Tania. 2007. Partidos y representación política: las dimensiones del cambio en los partidos políticos españoles, 1976-20o6. Madrid: CSIC.

VERSTRYNGE, Jorge. 1999. Memorias de un maldito. Barcelona: Grijalbo.

VIDAL-QUADRAS, Alejo. 1997. La derecha. Un intento de destilación axiológica. Barcelona: Destino.

Villacastín, Rosa. 1977. Alianza Popular: España, lo único importante. Madrid: Maisal. VIÑAs, Carles. 2004. Skinheads a Catalunya. Barcelona: Columna.

V.AA. 1997. Un hombre un voto. Guía electoral 1977. Madrid: Cambio 16.

WESTLE, Bettina \& Oskar NIEDER MAYER. 1992. «Contemporary right-wing extremism in West Germany. The Republicans and their electorate». European Journal of Political Research 22: 83-100. doi: 10.1111/j.1475-6765.1992.tboo306.x. 